\title{
ВіктOP ЗІНЧЕНКО
}

\section{МОДЕЛЬ ІНСТРУМЕНТАЛІЗМУ У ФІЛОСОФІЇ ОСВІТИ ПРАГМАТИЗМУ ТА НЕОПРАГМАТИЗМУ}

Аналізується системно-інтеграційний аспект соціальної філософії і менеджменту освіти у взаємодії концепцій інструменталізму прагматизму $i$ неопрагматизму у формуванні соціально-ціннісних орієнтацій. Досліджується інструменталістський аспект соціальної філософії та менеджменту освіти, психології та педагогіки концепцій

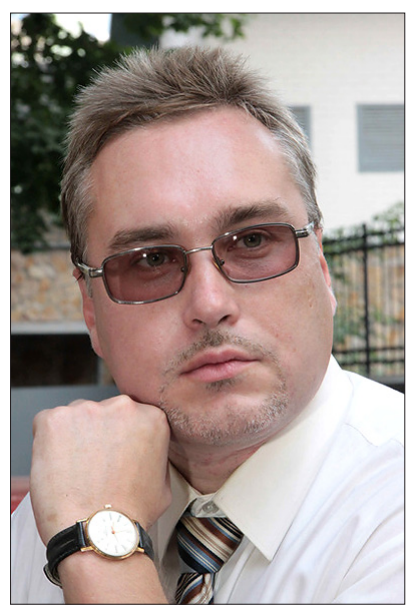
прагматизму і неопрагматизму як галузі управлінських знань про розвиток людини і суспільства. Здійснюється аналіз концепції менеджменту та філософії інструменталізму, а також класифікація сутності існуючих шкіл, напрямків, розкриваються ідейні протиріччя між ними.

Ключові слова: філософія освіти, інструменталізм, прагматизм, менеджмент, неопрагматизм, освіта, демократія, моральна свідомість, цінності, справедливість, принципи виховання, соціальні інститути.

Одним з небагатьох дослідників XX ст., які звернули пильну увагу на проблеми інтеграції соціальних наук, філософії освіти, педагогіки і менеджменту освіти/виховання, психології, був Дж.Дьюї - систематизатор концепції американського прагматизму, який створив його інструменталістську версію. Саме його філософська і педагогічна, управлінська й етична доктрини стали, як вже зазначалося, методологічною основою консервативного напрямку в філософії виховання.

«Найглибші сторони духовного ладу людини визначаються тим, як вона ставиться до проблем поведінки» (Дьюи, 1921: с.51) - писав Дьюї, вважаючи вкрай важливим філософське осмислення цих проблем. Більш того, філософію взагалі він широко розумів як «загальну теорію виховання, мета якої - реконструкція або реорганізація досвіду, яка підсилює здатність спрямовувати хід наступного досвіду» (Dewey, 1966: p.8990). Основне завдання майбутньої реконструйованої концепції він вбачав у тому, щоб «роз’яснювати людям ідеї, які стосуються як моральних, так і соціальних конфліктів повсякденного життя, і тим самим, у міру можливості, стати органом вирішення цих конфліктів» (Dewey, 1966: p.20). Таким чином, концепція освіти і виховання постає у Дьюї засобом відновлення, продовження соціального життя. 
3 ім'ям Дьюї на Заході довгий час асоціювалося філософське обгрунтування прогресивного розвитку систем освіти і виховання. Це було пов'язано, по-перше, з заявленою ним (поряд з іншими філософами кінця XIX-початку XX ст.) позицією про необхідність перейти від формалізму в оцінці поведінки людей, характерного для класичної етики, до телеології. Мова йшла про оцінку поведінки не з точки зору того, якою мірою вона відповідає незмінним, «вічним» моральним принципам, а 3 точки зору тих практичних результатів, які вчинки людей вносять у досягнення поставленої мети. Ця мета розумілася по-різному: одні ототожнювали ії з розвитком самосвідомості особистості, інші - з їі самовдосконаленням або цілісністю, треті - з граничним розвитком усіх людських здібностей тощо. Звичайно, саме по собі прагнення до такого повороту в оцінці поведінки людей відображало той факт, що в нових суспільних умовах абсолютні принципи, норми класичної етики вже «не працювали», був потрібний більш досконалий критерій оцінки поведінки в умовах постійно змінюваних чинників суспільного та індивідуального життя. Але у своєму конкретному вияві цей поворот знаменував собою перехід на позиції суб'єктивізму і релятивізму.

Здійснюючи його, Дьюї не міг не піддати гострій критиці панівні формальні методи менеджменту навчання та виховання, усю структуру середньої і вищої школи з характерною для неї відірваністю від життя, що також чимало сприяло його популярності як прихильника «прогресивної» системи виховання, управління та освіти. Популярність Дьюї пояснювалася ще й тим, що поряд з іншими реформаторами він виступив за створення наукової системи виховання, яка спирається на застосування «наукового методу» до питань моралі.

Що ж це за «науковий метод»? Він є невід'ємною частиною загального розуміння прагматизмом науки, ії методів, яке, по суті, применшувало значення наукової теорії. Нагадаємо, що, згідно з Дьюї, метод і засоби важливіші цілей і результатів дій людей. Наука має справу з конкретними ситуаціями або з конкретним досвідом, тому ії закони позбавлені загальної значущості, вони не більш ніж робочі гіпотези або інструменти, використовувані в досвіді. «Теорія - це теорія практики ... конструкція дії в думці» (Д'юї, 2003: с.43). Вона пропонує ряд підходів, ряд знарядь, з яких людина повинна якомусь віддати перевагу при вирішенні посталого завдання. Але спиратися у своєму виборі вона повинна на особистий досвід, на свій інтерес, намір.

Процес вибору теорії, за Дьюї, мало чим відрізняється від того, коли в залежності від свого наміру зробити щось конкретне тесляр вирішує взяти молоток, пилку або рубанок. Логічний процес також є відбором елементів системи, які відносяться до даного випадку. Цей індивідуа- 
лізований відбір і пристосування становлять невід’ємну частину логіки ситуації. Таким чином, поняття науки зводяться Дьюї до «інструментів», які довільно обираються людиною для пристосування їх до своїх інтересів в даній конкретній ситуації.

3 позицій такого загального уявлення про «наукову теорію», зведеної до «знаряддя», необхідного для вирішення практичних завдань, Дьюї підходить і до розуміння моралі, покликаної слугувати основою теорії виховання. Як і будь-яка теорія, моральна теорія є, згідно Дьюї, теорією практики, тобто ідеєю того, що повинно бути зроблено. Вона складається з повсякденних занять того ж звичайного розуму, який вимірює мануфактуру, вбиває цвяхи, продає пшеницю і винаходить телефон. «Різниця між ідеєю дитини про те, що вона повинна вивчити таблицю множення ... і найширшою моральною теорією - відмінність не якісного порядку, а лише в ступені аналізу практики» (Dewey, 1966: p.34) Але якщо від моральної теорії не потрібно нічого більше, як бути сумою «повсякденних занять звичайного розуму» і давати людині навики, як отримувати зі своїх вчинків вигоду, то навряд чи правомірно вважати іiі науковою теорією.

Виходячи, однак, саме з такого уявлення про сутність моральної теорії, Дьюї створює нову систему етики. На його думку, її новизна, іiі наукова основа полягає у тому, що вона будується у зв’язку з фактами, а останні вимагають головним чином критичного спрямування суджень. Потрібно знати, вважає Дьюї, яким буде результат будь-якої психічної схильності людини, іiї впливу на світогляд, а потім і на поведінку. 3'ясовуючи соціальну ситуацію, усвідомлюючи мотиви своїх дій і їхні наслідки, людина будує загальні положення, в яких виражається іiі досвід, зв'язки між обставинами. Ці положення використовуються і застосовуються для вирішення тих чи інших проблем у подальшому. Поступово їхнє вживання стає все більш звичним, і тоді соціальна ситуація приймає певну форму або організацію: «Подібно до того, як фізична наука призвела до організації фізичного світу, а також до організації практичних навиків поводження з цим світом, етична теорія викличе організацію світу суспільних явищ і відповідну організацію психічних звичок, за допомогою яких особистість пов'язує себе з цим світом» (Dewey, 1966: p.246-247).

Як бачимо, мораль і іï теорія в Дьюї не включають будь-яких стійких норм, пов’язаних з інтересами певних класів. Більш того, Дьюї вважає, що теза про класовий характер моралі та етики може слугувати лише руйнуванню суспільства та моральності. Різні класи створюють, міркує він, свої звичаї, які використовуються ними в якості власної робочої моралі. Кожен клас твердо переконаний у правоті своїх цілей i, отже, 
не надто педантичний щодо засобів їхнього досягнення. У сфері моралі немає ніякої спільної основи, відсутнє взаєморозуміння, згода у нормах поведінки. Ніколи раніше, вважає Дьюї, не було таких значних приводів для конфлікту, бо кожна з конфліктуючих сторін знаходила підтримку у своїх моральних принципах. «Розум, який є єдино можливим передвісником примирення, перебуває в далекій країні абстракцій, з'являючись вже після подіï, щоб дати звіт про здійснені факти» (Dewey, 1966: p.249). Якщо слідувати логіці Дьюї, виходить, що міцні моральні норми, корені яких знаходяться в реальних відносинах людей, слугують перешкодою для стійкості суспільства.

Дьюї заперечує наявність ідеалів, віддалених цілей, в ім'я яких люди, народні маси вступають на шлях боротьби. Він прагне створити універсальну етичну систему, яка слугувала б кожній людині незалежно від іiі соціального стану, досягненню іiі індивідуальної мети стосовно конкретної ситуації, її особистим поданням про благо, справедливість, рівності. Що ж стосується принципів, норм, правил, які постають з соціальних звичаїв, то вони, на думку Дьюї, є не що інше, як інтелектуальні інструменти, необхідні для аналізу конкретних ситуацій. Але ці інструменти ні в якій мірі не виконують функції моральних норм. Мораль, вважає Дьюї, потребує специфічних методів дослідження і винаходів для створення робочих гіпотез, які сприяють виявленню труднощів і зла. Тому «прагматистський внесок у логіку індивідуальних ситуацій, кожна 3 яких має своє власне незамінне благо і принципи, полягає у тому, щоб перенести увагу теорії від захоплення загальними концепціями до проблеми розвитку ефективних методів дослідження» (Dewey, 1966: p.170).

Дьюї правий, підкреслюючи, що, перш ніж прийняти рішення, людина повинна розібратися в конкретній ситуації. Моральна ситуація завжди проблематична, включає конфлікт, з якого потрібно знайти вихід (Zinchenko, 2016: p.45). При визначенні того, яким же чином людина шукає вихід з проблематичної ситуації, на що вона спирається у своєму виборі, Дьюї переносить центр ваги на людський розум. Саме йому відводиться функція за допомогою своїх «інструментів» проаналізувати ситуацію, встановити, що в ній є добром, а що - злом, і виробити відповідний план дій. Причому добро $i$ зло позбавлені, згідно Дьюї, cmaтусу загальних понять, вони унікальні для кожної ситуації. Більш того, визначення вчинків, явищ на кшталт, як добро чи зло, залежить тільки від критичного судження людини про дану ситуацію, про те, який вибір вона вважає за потрібне зробити в конкретному випадку, не дотримуючись при цьому будь-яких загальних закономірностей. Головне, що, на думку Дьюї, характеризує сутність вибору, - це можливість, яку ототожнюють із бажаністю. 
Дьюї не випадково замінює поняття історичної закономірності, необхідності поняттям можливості. 3 безлічі можливостей людина має право обирати ту, яка підказана йому самою ситуацією та забезпечує задоволення іiі бажань, отримання вигоди. Будь-яку ж дію відповідно до необхідності, із законами розвитку об'єктивної дійсності Дьюї розглядає як прояв фаталізму, заперечення свободи особистості. Але будьякий вибір, який здійснюється без опори на усвідомлену необхідність, стає свавіллям та в кінцевому підсумку - сліпим підпорядкуванням необхідності.

Прагнучи завуалювати волюнтаристський характер своєї позиції, Дьюї конкретизує іiі, обумовлюючи, що вибір, зроблений на основі одного лише бажання або смаку, не володіє моральною цінністю, бо існує відмінність між тим, що бажає людина, і тим, що об’єктивно бажано, між тим, що задовольняє людину, і тим, що є задовільним. Але формулюючи критерій цієї відмінності, Дьюї знову відверто стає па позиції волюнтаризму. Виявляється, правильний напрямок наших бажань і смаків можна надати не завдяки аналізу їхнього об'єктивного змісту. Тільки критичне судження людини щодо умов і результатів досвіду здатне спрямувати бажання та інтереси особистості з правильного шляху. «нттерес повинен не тільки спонукати особистість до судження, але й змушувати ії судити критично, використовуючи усі ресурси, якими вона володіє і які зможуть забезпечити найбільшу ймовірність істинності висновку» (Combs, 2013: р.175). Причини неправильного вибору, неправильної поведінки людини Дьюї шукає в iї психічних нахилах, які вплинули на характер її суджень. Іншими словами, ніякими об'єктивними обставинами ії поведінка не обумовлена, вона продукт лише ії власного Я.

Отже, поведінка людини, за Дьюї, позбавлена стійкої вищої мети, твердих принципів, норм, на які слід було б зважати при виборі своїх вчинків. Перед нею лише ситуація і вкладені в ній можливості, одній з яких вона надає перевагу згідно зі своїми бажаннями та інтересами. Причому останні багато в чому залежать, як ми вже відзначали, від іiі психічного стану. Такими є ті методологічні установки, на які спирався Дьюї при створенні своєї філософсько-педагогічної теорії виховання.

Концепція прагматизму і висхідна від неї теорія виховання у 1960ті роки втратили свою популярність. Проте вже до 1970-х років знову стало помітно їхнє пожвавлення у дещо модернізованому вигляді. Цьому сприяло, по-перше, поєднання у оновлених концепціях даного напрямку його висхідних позицій з ідеями інших світоглядних течій - неопозитивізму, екзистенціалізму, неофрейдизму, що дозволило збагатити категоріальний апарат і загальну теоретичну наповненість моделі освіти, управління і суспільного виховання прагматизму, зберігаючи при 
цьому дух концепції, сформульованої Дьюї. По-друге, зміни, яких зазнала концепція виховання прагматизму, дозволили їй вдало вписатися у посилену на цей час загальну тенденцію розуміння менеджменту виховання і освіти як процесу соціалізації особистості, її адаптації до існуючих цінностей західного суспільства.

Методологічні установки Дьюї з питань виховання в сучасних умовах поділяє група теоретиків, очолювана А.Маслоу, А.Комбсом, Е.Келлі, К.Роджерсом, Т.Брамельдом, С.Хуком та іншими (Див.: 3-8; 10-13). Вони підтримують положення Дьюї про роль виховання в суспільстві, про те, що цінність виховання залежить від того, якою мірою воно сприяє зростанню особистості, допомагає їй знайти відповіді на виникаючі повсякденні проблеми, а головне - вказує, як краще пристосуватися до даної ситуації, вижити в ній, бо життя - «перш за все постійний процес пристосування, не тільки біологічний, а й соціальний» (Talent, 2009: p.11).

Прихильники неопрагматистської конщепцї̈ освіти, виховання та менеджменту посилюють індивідуалістичну спрямованість ідей Дьюї, зближуючи в багатьох питаннях концепцію прагматизму з екзистенціалізмом. Слідом за Дьюї вони вважають, що задатки, здібності, таланти особистості носять вроджений характер, що основа їі творчого початку закладена в глибинах людського Я, навіть прагнення до самоуправління (самоменеджменту) також є вродженою. Тому, як зазначає А.Маслоу, природа людини документальна i, як правило, не піддається істотним змінам (Maslow, 1982: p.35). Саме тому не випадковим є його різко негативне ставлення до свідомої частини Я, якій ставиться функція контролю за людськими вчинками, самокритика.

Система виховання, згідно неопрагматизму, покликана виявити сутність вродженої природи людини і спиратися на неї. Моральне виховання, як іiї найважливіша частина, виходить, за Маслоу, з ієрархії вроджених людських потреб - починаючи від таких елементарних потреб, як потреба в їжі, продовження роду, до такої вищої потреби, як самоактуалізація особистості.

Завдання вищих і середніх навчальних закладів полягає у тому, щоб більше уваги приділяти унікальному досвіду учнів, формуванню їхньої індивідуальності, використовуючи в процесі навчання в міру можливості усі дисципліни навчального плану. Школа повинна служити лабораторією для відкриття унікального Я кожного учня, бо лише тільки тоді він отримає можливість пізнати навколишній світ.

Як бачимо, слідом за Дьюї його сучасні послідовники визнають, що закладені в природі людини здібності повинні мати можливість проявитися, а допомогти цьому покликана система виховання. Але якщо Дьюї пов’язував можливість прояву і зростання здібностей людини зі 
ступенем їі соціалізації і прагнув підпорядкувати виховання інтересам демократії, то неопрагматисти, подібно екзистенціалістам, стверджують, що поведінка людини є повністю самодетермінованою, що кожна особистість є власним проектом, сама себе творить у процесі вільного вибору. «Джерела зростання і гуманності особистості, - пише Маслоу, - знаходяться в самій особистості, вони ні в якій мірі не створені суспільством. Останнє може лише допомогти чи перешкодити зростанню гуманності людини, подібно до того як садівник може допомогти або перешкодити росту куща троянд, але він не може визначати, щоб замість куща троянд виріс дуб» (Maslow, 1987: p.36). I хоча Маслоу усвідомлює важливість для розвитку особистості культури, мови, абстрактного мислення, моральних якостей (особливо здатності любити іншу людину), він приходить до висновку, що актуалізація особистості (тобто найбільш повне вираження усіх іiі можливостей та здібностей) пов’язана лише з ії внутрішнім світом, оскільки тільки сама особистість знає, що є для неї добром, бо добро не можна визначити, підтвердити посиланням на об’єктивні факти, його можна тільки відчувати; добро є те, що викликає у людини почуття задоволення

Звичайно, добро пов'язане з почуттям задоволення, але основою цього почуття служить об’єктивний зміст вчинків, які сприятливо впливають не тільки на тих, хто їх скоїв, але й на інших людей, в оптимальному варіанті - на все суспільство. При цьому вчинки повинні відповідати критерію моральності - об’єктивно сприяти розвитку особистості і суспільства. Якщо ж, слідуючи Маслоу, пов’язувати добро тільки з відчутим людиною почуттям задоволення, то не можна оцінити реальний моральний зміст здійснених нею вчинків.

Подібно до того як пізнання, згідно неопрагматистам, є формуванням самою особистістю свого погляду на світ незалежно від його об’єктивних законів, поведінка людини - це лише самовираження, вільне від будь-яких принципів, громадських зв'язків, норм моралі і т. ін. Людині немає необхідності постійно формувати свою поведінку в залежності від відносин з оточуючими їі людьми, пристосовуватися до них, приховуючи від них щось сокровенне, або їх обманювати, тому що всі їі дії мотивовані цінністю свого Я.

Людина не має потреби у пошуках засновків своїх дій поза самою собою, своїми власними роздумами і оцінками. Оточуючі ï люди, їхня думка, суспільні норми та принципи не можуть служити підставою для вибору, бо їхня функція полягає в контролі, критиці поведінки людини, і тому вони можуть тільки заважати іiі самовираженню, іiі зростанню. Іншими словами, неопрагматисти відстоюють повне свавілля у вчинках і оцінках особистості. Причому в такого роду поведінці особистості вони 
вбачають джерело ії активності і оптимізму, оскільки у своїх діях вона нічим не зв'язана, керується лише своїми бажаннями, своєю волею.

Розвиваючи цю думку, А.Комбс стверджує, що для формування поведінки особистості важливіше за все з'ясувати, як вона дивиться на себе і на навколишній світ. Якщо вона впевнена в собі, то в неї немає підстав турбуватися про характер цінностей, якими вона керується (Combs, 1999: p.31). Таким чином, задоволення особистості собою, своїми діями, уявленнями, впевненість у собі постає як єдина гарантія її позитивного погляду на світ. Виявляється, що людині немає потреби знати істинний зміст подій, судити про поведінку інших людей за їхніми конкретними вчинками, досить самій перебувати в гарному настрої, бути задоволеним своїм становищем і поведінкою, щоб відповідно сприймати всіх оточуючих людей і події.

Очевидно, що неопрагматисти формують в певній мірі дещо некритичне, бездумне ставлення людини до життя, яке в кінцевому рахунку служить збереженню стійкості існуючої системи. Характерним є у цьому відношенні висловлювання А.Комбса, що особистість, яка відчуває себе задоволеною, здатна до дружби з усіма людьми, включаючи тих, хто знаходиться з нею в антагонізмі (Combs, 1962: p.50). Більш того, Комбс, ставлячи усю поведінку особистості в залежність від ії почуття задоволеності, виправдовує факти ухилення від якихось дій і рішень, до яких спонукає середовище. Як і Дьюї, Комбс проти «високих цілей». Він вважає, що люди, які добре знають себе, свої бажання, завжди ставлять перед собою цілком реалістичні, легко здійсненні цілі. А це, у свою чергу, породжує позитивні емоції у людини, закладає основу для гарного морального стану. Комбс проповідує терпимість до невизначеності, позитивно оцінюючи людей, які «знаходять можливим жити зручно з невирішеними проблемами» (Combs, 2013: p.137).

Іншими словами, він відкрито закликає людей до конформізму, вкладаючи в такого роду поведінку позитивний моральний сенс. 3 точки зору Комбса, схильні до конформізму люди дуже реалістично дивляться на мету своїх дій, вибираючи ту, яка найбільшою мірою відповідає їхнім здібностям. І це є основою успіху особистості, іiі гарного морального стану. Звідси випливає, що виховання ні в якій мірі не повинне налаштовувати особистість на зміну свого соціального статусу. Воно покликане головним чином навчити людину відчувати себе щасливою на тому ступені суспільного становища, який вона займає з волі обставин, навчити їі керуватися в житті тільки своїм самопочуттям. Привчити людину всюди і скрізь відчувати себе задоволеною - ось основна мета виховання, не позбавлена, якщо вдуматися, певного соціального грунту. 
Поведінка, яка спирається не на пізнання об’єктивного змісту ситуації, а тільки на власне сприйняття іiї людиною, носить, по суті, релятивістський характер, в ній немає нічого сталого, вона підкоряється лише миттєвим інтересам. «Стимул, яким людина керується у своєму виборі, виростає з даного моменту і не може бути ніким заздалегідь передбачений» - стверджує К.Роджерс (Rogers, 2012: p.21-23). Не можна передбачити результат поведінки, що є наслідком миттєвої ситуації, і тому вона не може бути пов'язаною з віддаленими цілями. «Людина, - стверджує Келлі, - не повина шукати міцної основи свого майбутнього. В одному лише вона може бути впевненою, коли мова йде про перспективи, - завтрашній день буде іншим, ніж сьогоднішній» (Kelly, 2002: p.19).

Бажання передбачити майбутнє, здійснення якого недоступне людині, може лише сковувати ії дії, бо активність людини буде насичуватися безглуздою надією на поліпшення.

Отже, жити сьогоденням і не думати про майбутне, підпорядковувати усі свої вчинки почуттю задоволеності, не роздумуючи про справжню основу цього почуття, - ось основне кредо концепції виховання неопрагматизму, яка незалежно від суб'єктивного бажання тих чи інших прихильників цього напряму може бути використана для виправдання моралі вседозволеності.

Поглиблюючи певний антиінтелектуалізм концепції Дьюї, сучасні представники неопрагматистської концепції розвитку людини, менеджменту виховання, яка увібрала в себе деякі ідеї екзистенціалізму, стверджують, що самовираження особистості досягається не розумом, а тільки почуттями, що ця поведінка людини є продуктом сприйняття певних явищ у момент здійснення нею вчинку. Тому вона сама спрямовує свою поведінку за допомогою тих даних, які вона відкрила для себе в безпосередньому чуттєвому досвіді. Звідси випливає, що характер поведінки особистості, скоєних нею вчинків визначається не їхнім об'єктивним змістом, але метою, якій вони були підпорядковані, і не наслідками, до яких вони призводять, а тим, як уявляються людині явища, обставини, з яких вона виходить у своїх вчинках, і ті люди, до яких вони мають відношення. Інакше кажучи, неопрагматисти надають значення лише самооцінці поведінки, виключаючи яку б то не було ії оцінку 3 боку інших людей, суспільства.

\section{Література:}

1. Дьюи Дж. Введение в философию воспитания. - М., 1921. - 62 с.

2. Д'юї Дж. Демократія і освіта. - Львів: Літопис, 2003. - 289 с.

3. Combs A. Humanism, education and future. - Boston: Educational Leadership, 2013. $-301 \mathrm{p}$. 
4. Combs A. W. (Author), David N. Aspy, Doris M. Brown, Morrrel J. Clute, Laurabeth H. Hicks, Elizabeth S. Randolph. Humanistic Education: Objectives and Assessment. - Washington, DC: Association for Supervision and Curriculum Development, 1978. $-255 \mathrm{p}$.

5. Combs A.W., Ann B. Miser, Kathryn S. Whitaker. On Becoming a School Leader: A Person-Centered Challenge. - Washington, DC: Association for Supervision \& Curriculum Deve, 1999. - 231 p.

6. Combs A.W. Perceiving, Behaving, Becoming: A New Focus for Education. Alexandria: Assn for Supervision \& Curriculum, 1962. - 127 p.

7. Combs A. W. Personal Approach to Teaching: Beliefs That Make a Difference. - Boston: Allyn \& Bacon, 1982. - $194 \mathrm{p}$

8. Combs A. W.The Schools We Need: New Assumptions for Educational Reform.Lanham, MD: University Press of America, 2011. - 178 p.

9. Dewey J. Democracy and education. New York: The Free Press, Macmillan Company, 1966. - $212 \mathrm{p}$.

10. Kelly E. The fully functioning self. - In.: Combs A. (ed) Perceiving, Behaving, Becoming: A New Focus for Education. - Assn for Supervision \& Curriculum, 2002. $-127 \mathrm{p}$.

11. Maslow A.H. Motivation and Personality. - Scotland: Harper Collins Publishers, 1987. $-293 \mathrm{p}$

12. Maslow A. Some basic proposition of growth and self. Actualization psychology. - In.: Combs A. (ed) Perceiving, Behaving, Becoming: A New Focus for Education. - Assn for Supervision \& Curriculum, 1982. - $127 \mathrm{p}$.

13. Rogers Carl R. Toward Becoming a Fully Functioning Person. - In: Perceiving, Behaving, Becoming: A New Focus for Education. Yearbook. Ed. A. W. Combs (edited by A. W. Combs). - Washington, DC: Association for Supervision and Curriculum Development, 2012. - $256 \mathrm{p}$.

14. Talent N. Psychology of Adjustment. - N.-Y: Routledge, 2009. - 298 p.

15. Zinchenko V.V. The Education in techno-structures of Society // The Culture and Power of Knowledge: Inquiries into Contemporary Societies. - 2016. - P.39-50.

\section{Виктор Зинченко. Модель инструментализма в философии образования прагматизма и неопрагматизма}

Анализируется системно-интегративный аспект социальной философии и менеджмента образования во взаимодействии концепций инструментализма прагматизма и неопрагматизма в формировании социальноценностных ориентаций. Исследуется инструменталистский аспект социальной философии и менеджмента образования, психологии и педагогики прагматизма и неопрагматизма как отрасли управленческих знаний о развитии человека и общества. Осуществляется анализ концепции менеджмента и философии инструментализма, а также классификация сущности существующих школ, направлений, раскрываются идейные противоречия между ними. 
Ключевые слова: философия образования, инструментализм, прагматизм, менеджмент, неопрагматизм, образование, демократия, моральное сознание, ценности, справедливость, принципы воспитания, социальные институты.

Viktor Zinchenko. Model of instrumentalism in the philosophy of education of pragmatism and neopragmatism

To analyse system-integration aspect of social philosophy and education management in interaction of concepts of an instrumentalism of a pragmatism and a neopragmatism in formation of socially valuable orientations. We study the instrumentalist aspect of social philosophy and management of education, psychology and pedagogy concepts of pragmatism and neopragmatism as industry management knowledge about the development of man and society. Carried out an analysis of the concept of management and philosophy of instrumentalism, and classification of the essence of the existing schools, trends are revealed ideological contradictions between them. .

Keywords: philosophy of education, instrumentalism, pragmatism, management, neopragmatism, education, democracy, moral consciousness, values, justice, principles of education, social institutes.

Зінченко Віктор Вікторович, доктор філософських наук, професор, головний науковий співробітник Інституту вищої освіти Національної академії педагогічних наук України.

E-mail: zinchenko@kiev.com.ua

Zinchenko Viktor Viktorovych, Doctor of philosophical sciences, professor, principal researcher, Institute of Higher Education at the National Academy of Educational Sciences of Ukraine.

E-mail: zinchenko@kiev.com.ua 